\title{
EFFECTIVE APPROACH IN MAKING CAPSTONE PROJECT A HOLISTIC LEARNING EXPERIENCE TO STUDENTS OF UNDERGRADUATE COMPUTER SCIENCE ENGINEERING PROGRAM
}

\author{
N. Deepamala $i D$, G. Shobha $i D$ \\ R.V. College of Engineering (India) \\ deepamalan@rvce.edu.in,shobhag@rvce.edu.in
}

Received March 2018

Accepted July 2018

\section{Abstract}

Final year or Capstone Project is the final and important phase of the undergraduate curriculum in a Computer Science Engineering program. Final year project is a course where all the skills learnt by the students in the course are applied and evaluated. The important aspects in the delivery of this course are (i) developing a model to train the students to deliver quality project work and documentation, (ii) effective evaluation of the student based on rubrics which are mapped to the course outcomes (iii) Calculate program outcome and course outcome attainment and make necessary changes to improve the delivery of the course (iv) Map the feedback from stakeholders as per graduate attributes and measure performance. This paper discusses the approach followed for three academic years 2014-2017 on a batch of 180 students per year. Training sessions, evaluation rubrics, usage of project management tools, mapping performance of the students with the outcomes of the course and program, feedback from the stakeholders like companies and students themselves gives a clear view of improvement of the performance of the students during the Final Year Project course in three years.

Keywords - Project Based Learning, Final year project, Computer science and Engineering, Higher education.

\section{To cite this article:}

Deepamala, N., \& Shobha, G. (2018). Effective approach in making capstone project a holistic learning experience to students of undergraduate computer science engineering program. Journal of Technology and Science Education, 8(4), 420-438. https:/ /doi.org/10.3926/jotse.427

\section{Introduction}

Final year project (FYP) is where undergraduate students of engineering courses undertake a project work as a part of their final year academics. These projects can be of 2 types, they can be live projects carried out at an industry on one of the real time industry problems, or they can be in-house projects which are carried out within the department over one of the research topics in any subject. Every project is an extensive learning experience for the student and a platform to apply everything that he/she has learnt throughout the course. The importance of a final year project in the program is summed up in the following points: 
a. Final year project is the only major course in a complete semester spanning for six months.

b. Final year project alone fetches 18 credits to a student.

c. Students carry out the project individually or in groups containing up to four students.

d. Students get an opportunity to execute live projects in the industry.

e. Programming Languages like C++, Java, Python etc., and subjects like Data Structures Computer Networks, Software Engineering and varied electives learnt in lower semesters are put into practical application.

f. FYP is one of the major criteria to calculate the outcome of the engineering program.

Over the delivery of the course in the previous years, many observations were made which needed modifications to increase the effectiveness of the course. Following are the observations that were modified for improvement from academic year 2014-15 onwards:

a. Rubrics for the projects were not exhaustive and required changes based on the attainment of outcomes.

b. Clearly defined course and program outcome was required to map the rubrics and feedback to evaluate the outcome and to improve the program.

c. Incorporation of continuous evaluation of project progress and emphasis on product development cycle (PDC) at each phase was necessary.

d. Students tended not to consider society, environment and interdisciplinary projects unless emphasized. Hence changes were to be made in the rubrics and training.

e. Conduction of workshops at different phases to motivate and train the students about synopsis writing, project management (Gantt chart), project design and effective report writing for the project was additionally planned.

f. Industry-academia relationship needed improvement which could be achieved by extensive feedback from the industry and the students.

g. Effective documentation and storage of project reports was essential for future reference.

h. Continuation of project titles for the next academic year was crucial for completion of long projects. If students have worked on a particular topic for first year, the next batch continues the work based on the scope for future developments in the topic.

\section{Literature Review}

Problem based learning and project based learning are two popular learning mechanisms in higher education. In problem based learning, students solve open ended problems to understand the concepts. On the other hand, project based learning is a learning mechanism where the course goes on for a specific duration with the outcome of a product or presentation with some analysis. Blumenfeld, Soloway, Marx, Krajcik, Guzdial and Palincsar (1991) explain how to motivate students to investigate and solve non-trivial problems, the difficulties faced in problem based learning and how they can be solved. The role of teachers and technology in motivating students, assessment of the project work and management of project are discussed. Mills and Treagust (2003) discuss the application of problem based and project based learning to engineering students. They stress on the importance of project based learning compared to "chalk and talk" method. Many institutions that incorporate traditionally taught courses mixed with project based components are reviewed and it is concluded that this method is readily accepted by students, industry and accreditors.

Bell brings out the importance of project based learning in the $21^{\text {st }}$ century in Bell (2010). Learning responsibility, independence and discipline are the three important outcomes of project based learning. 
The author further discusses how project based learning enhances creativity, real world connections, collaboration skills and technology. Krajcik et al. discuss the steps in carrying out a project based learning process in detail (Krajcik \& Blumenfeld, 2006). According to the authors, the key features in project based learning are driving questions, situated inquiry, collaboration, learning technologies and artifacts.

Engineering final year projects have been studied in detail in many papers. Ku and Goh (2010) emphasize that individual project were more effective in Europe and Australia. More students published papers in case of individual projects. Healey, Lannin, Stibbe and Derounian (2013) explain ways to enhance final year project and dissertation work. Stages and processes involved in final year project assessment in the University of Bath were discussed in Harris and Smith (1983).

Impact of program outcome, implementation and the factors that affect the outcome are discussed in Durlak and DuPre (2008) and Darling-Hammond (2006). Importance of rubrics and its effect on evaluation has been studied in detail in Stevens and Levi (2013). Outcome based evaluation and assessment of capstone project are discussed in Vijayalakshmi, Desai and Joshi (2013) and Dunlap (2005). The studies and suggestion in all these reference articles have been applied into the curriculum execution and results of these observations are discussed in this article.

\section{Continuous Evaluation of the Project Work}

A project work involves many tasks, beginning from the inception of a topic to the final submission of the dissertation. It is necessary to introduce a process of continuous evaluation of the project to ensure effective progress of the project work and its adherence to schedule. The student evaluation is carried out based on rubrics which are mapped to the course outcomes. Conduction and evaluation of the project is split into five phases. Each phase covers an important part of the Product Development Cycle (PDC). A committee is set up for the evaluation process. During the three academic years 2014-2017 the total number of projects is given below in Table 1.

\begin{tabular}{|c|r|r|r|r|r|}
\hline \multirow{2}{*}{ Academic Year } & \multirow{2}{*}{$\begin{array}{c}\text { Total Number } \\
\text { of Project } \\
\text { teams }\end{array}$} & \multicolumn{2}{|c|}{ Industry Live Projects } & \multicolumn{2}{|c|}{ In-House Projects } \\
\cline { 3 - 7 } & \multicolumn{2}{|c|}{ Count } & In percentage & Count & In percentage \\
\hline $2016-17$ & 120 & 82 & $69 \%$ & 38 & $31 \%$ \\
\hline $2015-16$ & 89 & 66 & $75 \%$ & 23 & $25 \%$ \\
\hline $2014-15$ & 80 & 46 & $58 \%$ & 34 & $42 \%$ \\
\hline
\end{tabular}

Table 1. Count of In-house and Industry projects

\subsection{Project Committees for Evaluation}

In Computer Science and Engineering, projects can be broadly classified as Computer Vision, Data Mining, Business Intelligence, Networking and Wireless Technologies. All the projects are largely classified into these domains. Committee members for evaluation are chosen from the faculty of Computer Science and Engineering department and also related departments like Information Science and Engineering and Mathematics. Evaluation is considered as part of academic work and academic workload units are assigned per week for the faculty who are committee members. This helps the faculty to dedicate time for students who require suggestions and feedback related to their projects. The projects are further divided into application, product and research, based on its type as shown in Table 2. The classification of projects helps the committee in evaluation. For example, more emphasis should be given to comparison of models than output in case of research projects. 


\begin{tabular}{|c|c|c|c|}
\hline \multirow{2}{*}{ Domain } & \multicolumn{3}{|c|}{ 2016-17 } \\
\hline & Application & Product & Research \\
\hline Networking & 15 & 5 & 2 \\
\hline Wireless Technologies & 13 & 3 & 2 \\
\hline Data Mining & 10 & 4 & 4 \\
\hline Business Intelligence & 34 & 3 & 1 \\
\hline Computer Vision & 8 & 2 & 14 \\
\hline Total & \multicolumn{3}{|r|}{120} \\
\hline Domain & \multicolumn{3}{|c|}{$2015-16$} \\
\hline Networking & 7 & 6 & 6 \\
\hline Wireless Technologies & 5 & 3 & 3 \\
\hline Data Mining & 19 & & 5 \\
\hline Business Intelligence & 19 & & 4 \\
\hline Computer Vision & 4 & & 8 \\
\hline Total & \multicolumn{3}{|r|}{89} \\
\hline Domain & \multicolumn{3}{|c|}{ 2014-15 } \\
\hline Networking & 13 & 2 & 5 \\
\hline Wireless Technologies & 9 & 1 & 3 \\
\hline Data Mining & 9 & & 7 \\
\hline Business Intelligence & 11 & 1 & 2 \\
\hline Computer Vision & 5 & 1 & 11 \\
\hline Total & \multicolumn{3}{|r|}{80} \\
\hline
\end{tabular}

Table 2. Types of Projects with domains

\subsection{Project Topic Collection and Dissemination}

Project topics allocation is done in two ways. For in-house projects, the topics are collected from the faculty members and communicated to the students through group email in the previous semester. The students then make groups and select topics from the list. On the other hand, if the student opts for a live industry project, the industry assigns the topic to the students which they then communicate to the department. Once these processes are done, the students finalize their topics by submitting a topic finalization form and a synopsis.

After the finalization, these topics are evaluated by the committee for approval where the students submit their project synopsis. Approval of the topic by the committee is a necessity for further continuation of the project. Once the approval is initiated, guides are allocated to the individual students and student teams based on the topics and the subject expertise of the faculty in those topics.

\subsection{Project Phases and Rubrics}

Project Phases are related to Product Development Cycle (PDC). The phases and their main tasks are shown in the Figure 1. 


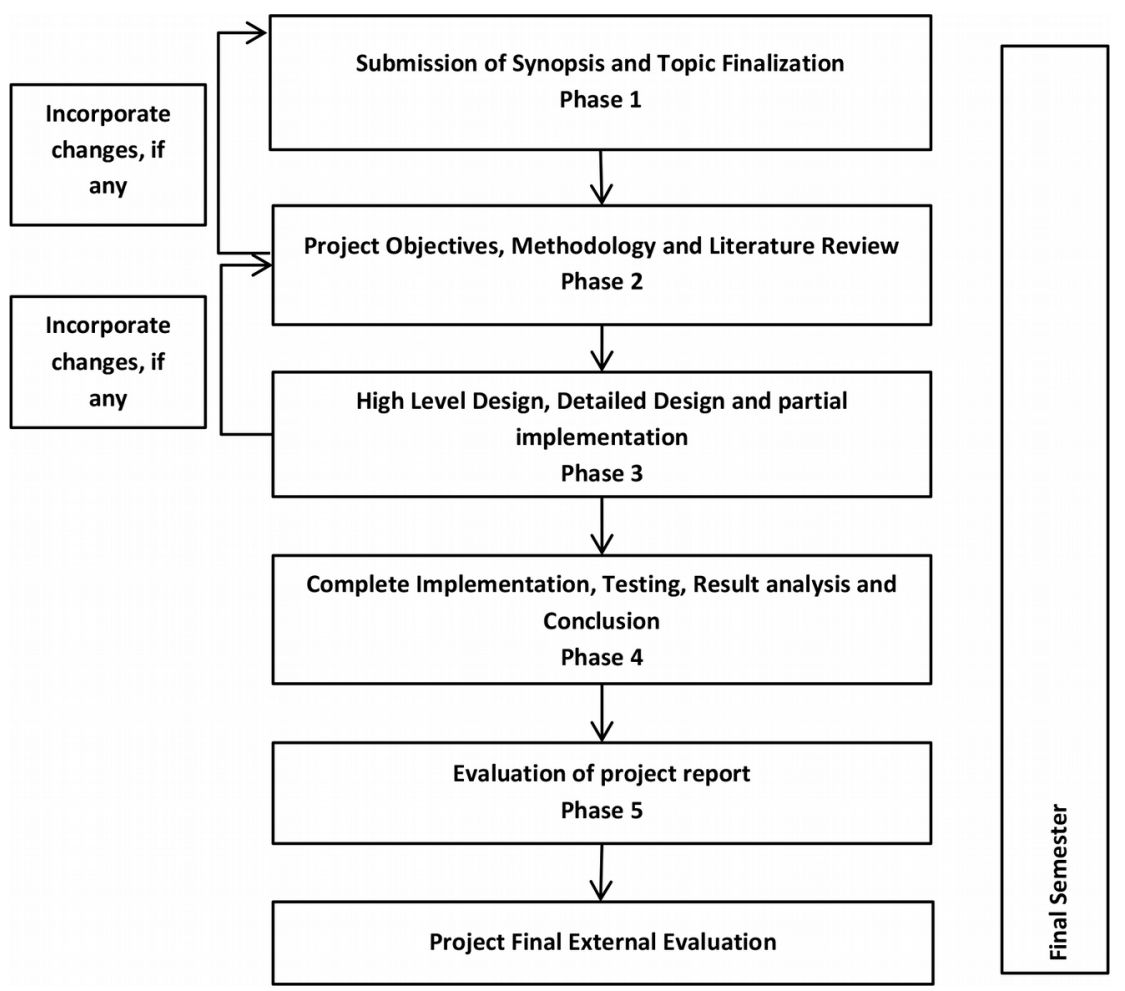

Figure 1. Various steps in evaluation of Major Project

\subsubsection{Phase 1}

Phase 1 is the initial phase where the project teams will finalize their topics, submit a synopsis presenting the methodology, objectives and scope of the project. Rubrics are defined for the marks allocation. Contribution of the project towards the society, environment, interdiciplinary scope are considered during the evaluation. Further, a training session is organized for the students on the selection of a topic, during this phase.

\section{Training 1: Workshop on "Selection of Project Topic"}

This first training session is conducted at the beginning of the semester to explain the importance of taking projects related to society, environment and also motivate students to take up interdisciplinary projects. The topic of synopsis writing is also explained to the students in this session. Conduction of project work through phases, importance of project management, team structure, etc. are explained to the students. The students are also trained in the usage of tools like Gantt chart. The details of the rubrics for Phase 1 are listed below in Table 3.

\subsubsection{Phase 2}

The details of the rubrics of Phase 2 are listed in Table 4.

In Phase 2, the students present a detailed methodology of the project to the committee. If the committee believes that the methodology is not appropriate or there is a better way to conduct the experiments, the teams are advised about the changes. Emphasis is given on the study of literature and gaps in the research. Phase 2 also encourages the students to demonstrate project management skills in the form of project planning and team structure. Students present the project planning in the form of a Gantt chart, i.e. a pictorial representation of the project plan with milestones and the planned dates of completion of each milestone. Both the guide and the committee evaluate the presentation given by the project teams based on the rubrics. A sample of a Gantt chart is as shown in Figure 2. 


\begin{tabular}{|c|c|c|c|c|c|}
\hline & & Excellent & Good & Satisfactory & Poor \\
\hline a. & $\begin{array}{l}\text { Identification } \\
\text { of Problem in } \\
\text { the Program } \\
\text { Domain } \\
\text { CO1 }\end{array}$ & $\begin{array}{l}\text { - Project Topic } \\
\text { clearly defines the } \\
\text { project work to be } \\
\text { undertaken. } \\
\text { - Problem statement } \\
\text { is unique in the } \\
\text { domain and has } \\
\text { scope for research } \\
\text { work and outcome } \\
\text { in the form of } \\
\text { publication, patent } \\
\text { etc. }\end{array}$ & $\begin{array}{l}\text { - Project Topic } \\
\text { clearly defines the } \\
\text { project work to be } \\
\text { undertaken. } \\
\text { - Problem statement } \\
\text { is unique in the } \\
\text { domain but has } \\
\text { limited scope for } \\
\text { research and } \\
\text { outcome in the } \\
\text { form of } \\
\text { publication, patent } \\
\text { etc. }\end{array}$ & $\begin{array}{l}\text { - Project Topic is } \\
\text { not clearly } \\
\text { defined. } \\
\text { - Uniqueness of the } \\
\text { problem in the } \\
\text { domain is not } \\
\text { clearly justified. }\end{array}$ & $\begin{array}{l}\text { - Problem statement } \\
\text { not unique, need } \\
\text { change of topic or } \\
\text { modification in } \\
\text { the problem } \\
\text { definition. }\end{array}$ \\
\hline b. & $\begin{array}{l}\text { Existing Systems } \\
\text { and Feasibility } \\
\text { of Project } \\
\text { Proposal } \\
\text { CO1 }\end{array}$ & $\begin{array}{l}\text { - Justifies the } \\
\text { project topic with } \\
\text { a brief survey of } \\
\text { the existing } \\
\text { systems and their } \\
\text { limitations with its } \\
\text { business value. }\end{array}$ & \begin{tabular}{|l|} 
- Justifies the \\
project with a \\
brief survey of \\
existing systems \\
without proper \\
justification of \\
their limitations \\
and business value.
\end{tabular} & $\begin{array}{l}\text { - Partial justification } \\
\text { to the project } \\
\text { topic with } \\
\text { improper } \\
\text { explanation of } \\
\text { existing systems, } \\
\text { their limitations } \\
\text { and market value. }\end{array}$ & $\begin{array}{l}\text { - Incomplete } \\
\text { justification to the } \\
\text { project topic with } \\
\text { improper } \\
\text { explanation of } \\
\text { existing systems, } \\
\text { their limitations } \\
\text { and market value. }\end{array}$ \\
\hline c. & $\begin{array}{l}\text { Objectives and } \\
\text { Methodology of } \\
\text { the Proposed } \\
\text { Work } \\
\text { CO2 }\end{array}$ & $\begin{array}{l}\text { - All objectives of } \\
\text { the proposed work } \\
\text { are well defined } \\
\text { and justified. } \\
\text { - Steps to be } \\
\text { followed in the } \\
\text { form of } \\
\text { methodology to } \\
\text { solve the defined } \\
\text { problem are } \\
\text { clearly specified. }\end{array}$ & 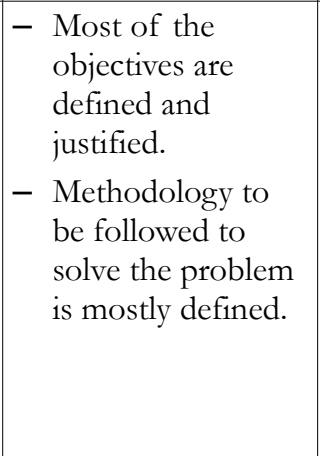 & $\begin{array}{l}\text { - } \text {-Incomplete } \\
\text { justification to the } \\
\text { objectives } \\
\text { proposed. } \\
\text { - }- \text { Steps mentioned } \\
\text { in methodology } \\
\text { are without } \\
\text { justification to } \\
\text { objectives. }\end{array}$ & $\begin{array}{l}- \text { Only few } \\
\text { objectives of the } \\
\text { proposed work are } \\
\text { well defined. } \\
\text { - } \text { Methodology } \\
\text { followed to solve } \\
\text { the defined } \\
\text { objectives is } \\
\text { poorly defined. }\end{array}$ \\
\hline d. & $\begin{array}{l}\text { Knowledge, } \\
\text { Skills, and } \\
\text { Research Base } \\
\text { leading to } \\
\text { interdisciplinary } \\
\text { project } \\
\text { CO1 }\end{array}$ & $\begin{array}{l}\text { - Demonstrates } \\
\text { deep } \\
\text { understanding of } \\
\text { the concepts and } \\
\text { tools related to the } \\
\text { project. } \\
\text { - Interdisciplinary } \\
\text { project with } \\
\text { contribution from } \\
\text { other domains is } \\
\text { demonstrated as } \\
\text { collaboration with } \\
\text { other department } \\
\text { students or teams } \\
\text { in industry. }\end{array}$ & \begin{tabular}{|l} 
- Demonstrates \\
deep \\
understanding of \\
the concepts and \\
tools related to the \\
project. \\
- Not an \\
interdisciplinary \\
project but has \\
notable \\
contribution to the \\
given domain.
\end{tabular} & $\begin{array}{l}\text { - Partial } \\
\text { understanding of } \\
\text { the concepts } \\
\text { related to the } \\
\text { project and its } \\
\text { scope. } \\
\text { - Not an } \\
\text { interdisciplinary } \\
\text { project and limited } \\
\text { contribution of } \\
\text { the project to the } \\
\text { domain. }\end{array}$ & $\begin{array}{l}\text { - Minimally } \\
\text { understands the } \\
\text { concepts related to } \\
\text { the project. } \\
\text { - Not an } \\
\text { interdisciplinary } \\
\text { project and limited } \\
\text { scope of the } \\
\text { project in the } \\
\text { given domain. }\end{array}$ \\
\hline e. & 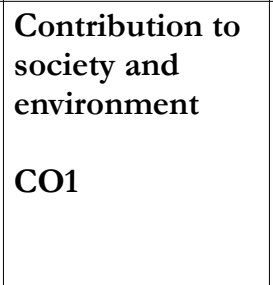 & $\begin{array}{l}\text { - Objective related } \\
\text { to environment or } \\
\text { society is } \\
\text { mentioned in the } \\
\text { project objective } \\
\text { and is of higher } \\
\text { significance. }\end{array}$ & $\begin{array}{l}\text { - Objective related } \\
\text { to environment } \\
\text { and society is } \\
\text { defined in the } \\
\text { objective but is of } \\
\text { lesser significance. }\end{array}$ & $\begin{array}{l}\text { - No defined } \\
\text { objective related to } \\
\text { environment or } \\
\text { society in the } \\
\text { project work. }\end{array}$ & \\
\hline
\end{tabular}

Table 3. Rubrics for Phase 1 with CO mapping 


\begin{tabular}{|c|c|c|c|c|c|}
\hline & & Excellent & Good & Average & Acceptable \\
\hline a. & $\begin{array}{l}\text { Knowledge, } \\
\text { Skills, and } \\
\text { Research Base } \\
\text { CO1 }\end{array}$ & $\begin{array}{l}\text { - Detailed study is } \\
\text { made on existing } \\
\text { systems and their } \\
\text { limitations. } \\
\text { - The surveyed } \\
\text { papers are } \\
\text { comprehensive to } \\
\text { the problem and } \\
\text { cover recent } \\
\text { developments. } \\
\text { - Demonstrates } \\
\text { superior use and } \\
\text { integration of } \\
\text { theory, research, } \\
\text { and best practices. }\end{array}$ & $\begin{array}{l}\text { - } \text {-Elaborate survey } \\
\text { of existing systems } \\
\text { and their } \\
\text { limitations. } \\
\text { - }- \text {-The surveyed } \\
\text { papers are not } \\
\text { comprehensive to } \\
\text { the problem and do } \\
\text { not cover recent } \\
\text { developments. } \\
\text { - Demonstrates high } \\
\text { quality in use and } \\
\text { integration of } \\
\text { theory, research, } \\
\text { and best practices. }\end{array}$ & 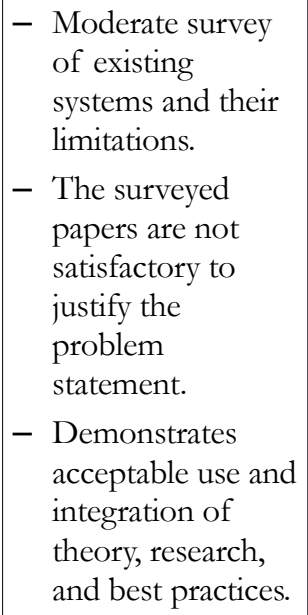 & $\begin{array}{l}\text { - Partial survey of } \\
\text { existing systems and } \\
\text { their limitations. } \\
\text { - } \text { The surveyed papers } \\
\text { are outdated and not } \\
\text { relevant. } \\
\text { - Demonstrates } \\
\text { minimum use and } \\
\text { integration of } \\
\text { theory, research, and } \\
\text { best practices. }\end{array}$ \\
\hline b. & $\begin{array}{l}\text { Design } \\
\text { Methodology }\end{array}$ & $\begin{array}{l}\text { - Accurate division } \\
\text { of problem into } \\
\text { modules and good } \\
\text { selection of } \\
\text { computing } \\
\text { framework. } \\
\text { - Appropriate } \\
\text { Design } \\
\text { methodology with } \\
\text { justification. }\end{array}$ & $\begin{array}{l}\text { - Accurate division } \\
\text { of problem into } \\
\text { modules but } \\
\text { improper selection } \\
\text { of computing } \\
\text { framework. } \\
\text { - Design } \\
\text { methodology is not } \\
\text { properly justified. }\end{array}$ & $\begin{aligned} &- \text { - } \text { Division of } \\
& \text { problem into } \\
& \text { modules correct } \\
& \text { but Inappropriate } \\
& \text { selection of } \\
& \text { computing } \\
& \text { framework. } \\
& \text { - } \text { Design } \\
& \text { - } \\
& \text { Methodology not } \\
& \text { defined properly. }\end{aligned}$ & 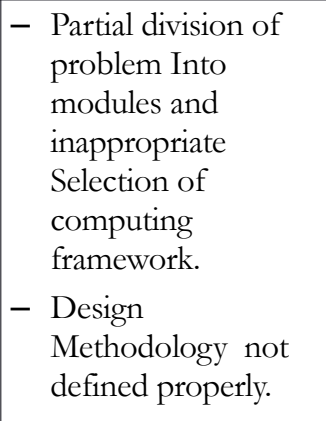 \\
\hline c. & $\begin{array}{l}\text { Planning of } \\
\text { Project Work } \\
\text { and Team } \\
\text { Structure }\end{array}$ & $\begin{array}{l}\text { - Project schedule } \\
\text { properly specified } \\
\text { as Gantt chart in } \\
\text { detail. } \\
\text { - Appropriate } \\
\text { distribution of } \\
\text { project work } \\
\text { among team } \\
\text { members. }\end{array}$ & $\begin{array}{l}\text { - Project schedule } \\
\text { properly specified } \\
\text { as Gantt chart. } \\
\text { - Inappropriate } \\
\text { distribution of } \\
\text { project work } \\
\text { among team } \\
\text { members. }\end{array}$ & $\begin{array}{l}\text { - Project schedule } \\
\text { not planned } \\
\text { properly. } \\
\text { - Distribution of } \\
\text { project work un- } \\
\text { even among team } \\
\text { members. }\end{array}$ & $\begin{array}{l}\text { - Project schedule } \\
\text { improperly } \\
\text { specified. } \\
\text { - Un-even distribution } \\
\text { of project work and } \\
\text { no synchronization. }\end{array}$ \\
\hline
\end{tabular}

Table 4. Rubrics for Phase 2 with CO mapping

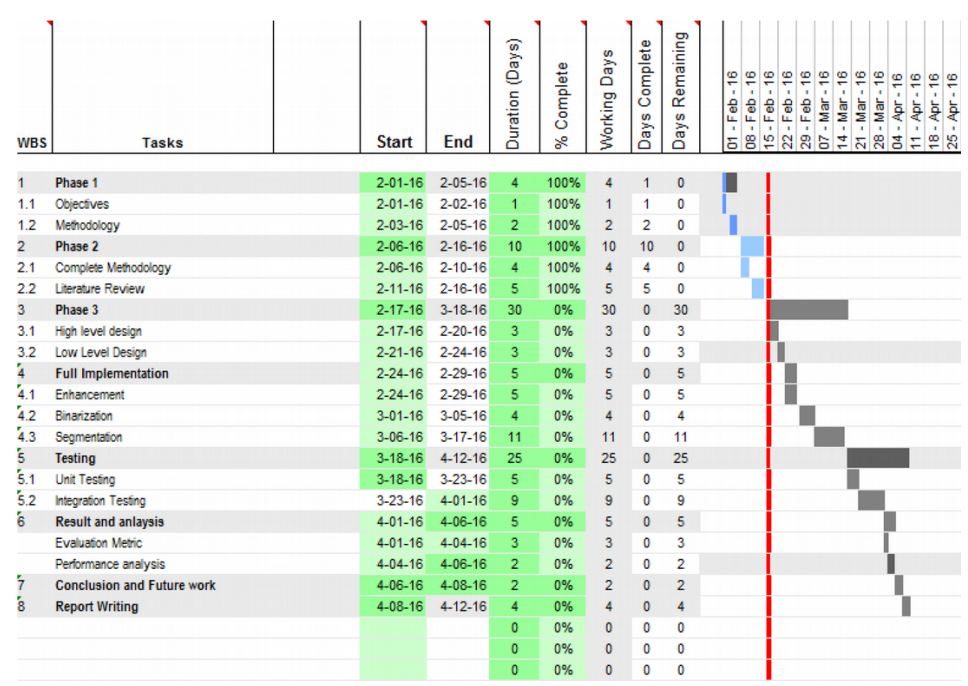

Figure 2. An example of a Gantt chart 


\subsubsection{Phase 3}

Phase 3 is the design phase where the students present a high level design and a detailed design of the project with the help of Data Flow Diagrams (DFDs), structure charts, flow charts and module descriptions. The committee evaluates the design and gives a feedback about it. Suggested changes, if any, are incorporated at this stage. Both the guide and the committee evaluate the work presented based on the rubrics. These rubrics are listed in Table 5 .

\begin{tabular}{|c|c|c|c|c|c|}
\hline & & Excellent & Good & Average & Acceptable \\
\hline a. & $\begin{array}{l}\text { Incorporation of } \\
\text { suggestions }\end{array}$ & \begin{tabular}{|l}
- Changes are made \\
as per modification \\
suggested during \\
evaluation of \\
phase 2 and new \\
innovations added.
\end{tabular} & $\begin{array}{l}\text { - Changes are made } \\
\text { as per } \\
\text { modifications } \\
\text { suggested during } \\
\text { evaluation of } \\
\text { phase } 2 \text { with good } \\
\text { justification. }\end{array}$ & $\begin{array}{l}\text { - All major changes } \\
\text { are incorporated as } \\
\text { per the } \\
\text { modifications } \\
\text { suggested during } \\
\text { evaluation of } \\
\text { phase } 2 .\end{array}$ & $\begin{array}{l}- \text { Few changes are } \\
\text { made as per } \\
\text { modifications } \\
\text { suggested during } \\
\text { evaluation of } \\
\text { phase } 2 .\end{array}$ \\
\hline b. & $\begin{array}{l}\text { High Level } \\
\text { Design } \\
\text { CO3 }\end{array}$ & $\begin{array}{l}\text { - Design of system } \\
\text { according to } \\
\text { appropriate } \\
\text { architectural model } \\
\text { and design adhere } \\
\text { to objectives } \\
\text { specified. } \\
\text { - Superior } \\
\text { representation of } \\
\text { project design in } \\
\text { the form of } \\
\text { DFDs, Use case } \\
\text { diagrams and } \\
\text { structure charts. }\end{array}$ & $\begin{array}{l}\text { - Design as per } \\
\text { architectural model } \\
\text { but not clearly } \\
\text { demonstrated. All } \\
\text { the objectives are } \\
\text { not covered. } \\
\text { - - Good } \\
\text { representation of } \\
\text { project design in } \\
\text { the form of } \\
\text { DFDs, Use case } \\
\text { diagrams and } \\
\text { structure charts. }\end{array}$ & $\begin{array}{l}\text { - Partially objectives } \\
\text { are covered in the } \\
\text { design. } \\
\text { - Partial } \\
\text { representation of } \\
\text { project design in } \\
\text { the form of } \\
\text { DFDs, Use case } \\
\text { diagrams and } \\
\text { structure charts. }\end{array}$ & $\begin{array}{l}\text { - Partially objectives } \\
\text { are covered in the } \\
\text { design. } \\
\text { - Incorrect } \\
\text { representation of } \\
\text { project design in } \\
\text { the form of } \\
\text { DFDs, Use case } \\
\text { diagrams and } \\
\text { structure charts. }\end{array}$ \\
\hline c. & $\begin{array}{l}\text { Detailed Design } \\
\mathrm{CO} 3\end{array}$ & $\begin{array}{l}\text { - Well-designed } \\
\text { module level } \\
\text { functional } \\
\text { description and } \\
\text { understanding of } \\
\text { computing } \\
\text { principles and } \\
\text { algorithms. }\end{array}$ & $\begin{array}{l}\text { - Well-designed } \\
\text { module level } \\
\text { functional } \\
\text { description and } \\
\text { understanding of } \\
\text { computing } \\
\text { principles and } \\
\text { algorithms but not } \\
\text { clearly } \\
\text { demonstrated. }\end{array}$ & $\begin{array}{l}\text { - Well-designed } \\
\text { module Level } \\
\text { functional } \\
\text { description and } \\
\text { partial } \\
\text { understanding of } \\
\text { computing } \\
\text { principles and } \\
\text { algorithms. }\end{array}$ & $\begin{array}{l}\text { - Partially designed } \\
\text { module Level } \\
\text { functional } \\
\text { description and } \\
\text { partial } \\
\text { understanding of } \\
\text { computing } \\
\text { principles and } \\
\text { algorithms. }\end{array}$ \\
\hline d. & $\begin{array}{l}\text { Partial } \\
\text { Implementation } \\
\text { CO3 }\end{array}$ & 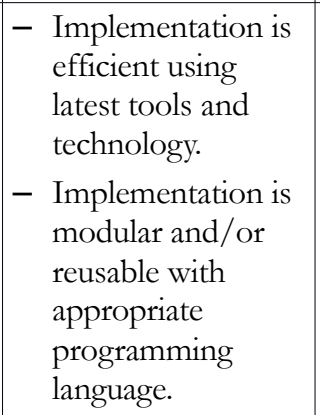 & $\begin{array}{l}\text { - Implementation is } \\
\text { partially efficient } \\
\text { using latest tools } \\
\text { and technology. } \\
\text { - Implementation is } \\
\text { modular and/or } \\
\text { reusable with } \\
\text { appropriate } \\
\text { programming } \\
\text { language. }\end{array}$ & $\begin{array}{l}\text { - Implementation is } \\
\text { partially efficient. } \\
\text { - Missing modular } \\
\text { programming and } \\
\text { wrong choice of } \\
\text { programming } \\
\text { language. }\end{array}$ & \\
\hline
\end{tabular}

Table 5. Rubrics for Phase 3 with CO mapping

\section{Training 2: Workshop on Writing Design Document}

A second training session is conducted in the middle of the semester to explain the importance and method of designing a product. Importance of Data Flow Diagrams (DFD), structure charts, UML diagrams, flow charts, etc. are explained to the students. Open source tools like ProjectLibre (Tsvetkov, 2015) for project management, GIthub (https://github.com/) for project sharing and starUML 
(StarUML, U.M.L., 2005) for drawing diagrams are introduced. Software design is already learnt in software engineering subjects in lower semesters, but students usually find it difficult to apply the concepts to real-time project. Correct representation of modules in the project in the form of diagrams and depiction of control and data flow requires training and feedback from the faculty.

\subsubsection{Phase 4}

In Phase 4, the project teams demonstrate the complete implementation of the modules, unit testing and integration testing with relevant result analyses. Students present the implementation of the project to the committee with the results of the testing. If any modifications are required in the implementation, students are given a week time to make these modifications. Students show a demo of their project during the presentation. Both the guide and committee members evaluate the work carried out by the students based on rubrics. These rubrics are listed in Table 6.

\begin{tabular}{|c|c|c|c|c|c|}
\hline & & Excellent & Good & Average & Acceptable \\
\hline a. & Implementation & $\begin{array}{l}\text { - The } \\
\text { implementation } \\
\text { consistent with } \\
\text { design, coding } \\
\text { standards and } \\
\text { optimized. Clear } \\
\text { and understandable } \\
\text { description of the } \\
\text { functional status of } \\
\text { each features or } \\
\text { modules. } \\
\text { - All algorithms are } \\
\text { clearly defined with } \\
\text { correct } \\
\text { representation. }\end{array}$ & $\begin{array}{l}\text { - The } \\
\text { implementation } \\
\text { consistent with } \\
\text { design, } \\
\text { understandable } \\
\text { but not clearly } \\
\text { defined. } \\
\text { - Algorithms are } \\
\text { defined with } \\
\text { correct } \\
\text { representations. }\end{array}$ & $\begin{array}{l}- \text { The } \\
\text { implementation } \\
\text { consistent with } \\
\text { design, most of } \\
\text { the functional } \\
\text { status of features } \\
\text { not } \\
\text { understandable. } \\
\text { - Algorithms are } \\
\text { partially } \\
\text { represented. }\end{array}$ & $\begin{array}{l}\text { - Implement } \\
\text { deviated from } \\
\text { design, no coding } \\
\text { standards and } \\
\text { partially } \\
\text { understandable. } \\
\text { - Improper } \\
\text { description of } \\
\text { algorithms and } \\
\text { representation. }\end{array}$ \\
\hline b. & Testing & $\begin{array}{l}\text { - Exhaustive } \\
\text { coverage of all test } \\
\text { cases related to } \\
\text { system testing, unit } \\
\text { testing and } \\
\text { Integration testing. } \\
\text { - Dataset, Evaluation } \\
\text { mechanism are } \\
\text { clearly mentioned. } \\
\text { - Test plan clearly } \\
\text { shows testing } \\
\text { assumptions, } \\
\text { constraints and test } \\
\text { results. }\end{array}$ & $\begin{array}{l}\text { - Most of the test } \\
\text { cases related to } \\
\text { system testing, } \\
\text { unit testing and } \\
\text { Integration testing } \\
\text { are covered. } \\
\text { - Dataset, } \\
\text { Evaluation } \\
\text { mechanism are } \\
\text { clearly mentioned. } \\
\text { - Test plan clearly } \\
\text { shows testing } \\
\text { assumptions, } \\
\text { constraints and } \\
\text { test results. }\end{array}$ & \begin{tabular}{|l} 
- \\
Partial coverage of \\
test cases related to \\
system testing, unit \\
testing and \\
Integration testing. \\
- Dataset, \\
Evaluation \\
mechanism are not \\
clearly mentioned. \\
- Test plan partially \\
shows testing \\
assumptions, \\
constraints and test \\
results.
\end{tabular} & $\begin{array}{l}\text { - } \text { Incomplete } \\
\text { coverage of test } \\
\text { cases related to } \\
\text { system testing, unit } \\
\text { testing and } \\
\text { Integration testing. } \\
\text { - Dataset, } \\
\text { Evaluation } \\
\text { mechanism are not } \\
\text { clearly mentioned. } \\
\text { - Test plans partially } \\
\text { shows testing } \\
\text { assumptions, } \\
\text { constraints and test } \\
\text { results. }\end{array}$ \\
\hline c. & $\begin{array}{l}\text { Experimental } \\
\text { Result and } \\
\text { analysis }\end{array}$ & $\begin{array}{l}\text { - The findings } \\
\text { logically map with } \\
\text { the design. } \\
\text { - Appropriate } \\
\text { statistical } \\
\text { analyses/graphs } \\
\text { used and results } \\
\text { correctly } \\
\text { interpreted. }\end{array}$ & $\begin{array}{l}\text { - The findings } \\
\text { partially logically } \\
\text { map with the } \\
\text { design. } \\
\text { - Appropriate } \\
\text { statistical } \\
\text { analyses/graphs } \\
\text { used and results } \\
\text { partially } \\
\text { interpreted. }\end{array}$ & $\begin{array}{l}\text { - The findings } \\
\text { partially logically } \\
\text { map with the } \\
\text { design. } \\
\text { - Not Appropriate } \\
\text { statistical } \\
\text { analyses/graphs } \\
\text { used and results } \\
\text { are partially } \\
\text { interpreted. }\end{array}$ & $\begin{array}{l}\text { - The findings does } \\
\text { not logically map } \\
\text { with the design. } \\
\text { - Incorrect statistical } \\
\text { analyses/graphs } \\
\text { used and results } \\
\text { are incorrect. }\end{array}$ \\
\hline
\end{tabular}




\begin{tabular}{|c|c|c|c|c|c|}
\hline & & Excellent & Good & Average & Acceptable \\
\hline d. & $\begin{array}{l}\text { Conclusion and } \\
\text { Future work } \\
\text { CO4 }\end{array}$ & $\begin{array}{l}\text { - } \text { The conclusion } \\
\text { effectively } \\
\text { summarizes the } \\
\text { results and } \\
\text { important ideas } \\
\text { without sounding } \\
\text { repetitive or } \\
\text { redundant. } \\
\text { - The future work } \\
\text { concludes with } \\
\text { thought provoking } \\
\text { details. }\end{array}$ & $\begin{array}{l}- \text { The conclusion } \\
\text { partially } \\
\text { summarizes the } \\
\text { results and } \\
\text { important ideas } \\
\text { without sounding } \\
\text { repetitive or } \\
\text { redundant. } \\
\text { - The future work } \\
\text { concludes with } \\
\text { thought provoking } \\
\text { details. }\end{array}$ & $\begin{array}{l}\text { - The conclusion } \\
\text { does not } \\
\text { summarize the } \\
\text { results and } \\
\text { important ideas } \\
\text { without sounding } \\
\text { repetitive or } \\
\text { redundant. } \\
\text { - The future work } \\
\text { does not conclude } \\
\text { with thought } \\
\text { provoking details. }\end{array}$ & \\
\hline e. & $\begin{array}{l}\text { Demo of the } \\
\text { project } \\
\text { CO4 }\end{array}$ & $\begin{array}{l}\text { - Demo shown and } \\
\text { complete. }\end{array}$ & $\begin{array}{l}\text { - Demo shown but } \\
\text { incomplete. }\end{array}$ & $\begin{array}{l}\text { - Demo shown but } \\
\text { with mistakes. }\end{array}$ & - No demo shown. \\
\hline
\end{tabular}

Table 6. Rubrics for Phase 4 with CO mapping

\subsubsection{Phase 5}

Phase 5 is the final phase, where the students document the project in the form of a project dissertation report. The student has to get the report verified by the guide initially and later by the committee. Finally, the project report with all the modifications completed, is checked for plagiarism and submitted to the department to be stored in the department library. These project dissertation reports are maintained in the department library for any future reference for the faculty and students. The rubrics for Phase 5 are listed in Table 7.

\begin{tabular}{|c|c|c|c|c|c|}
\hline & & Excellent & Good & Average & Acceptable \\
\hline a. & $\begin{array}{l}\text { Completeness } \\
\text { of the report } \\
\text { CO } 4\end{array}$ & $\begin{array}{l}\text { - The report is clear, } \\
\text { concise and } \\
\text { understandable. } \\
\text { - Technical } \\
\text { dependency, theory } \\
\text { and observation } \\
\text { clearly stated. }\end{array}$ & $\begin{array}{l}\text { - The report is } \\
\text { clear, concise and } \\
\text { understandable. } \\
\text { - Technical } \\
\text { dependency, } \\
\text { theory and } \\
\text { observation are } \\
\text { not clearly stated. }\end{array}$ & $\begin{array}{l}\text { - The report is partially } \\
\text { clear, concise and } \\
\text { understandable. } \\
\text { - Technical } \\
\text { dependency, theory } \\
\text { and observation not } \\
\text { clearly stated. }\end{array}$ & $\begin{array}{l}\text { - The report is } \\
\text { unclear, not concise } \\
\text { and not } \\
\text { understandable. } \\
\text { - Technical } \\
\text { dependency, theory } \\
\text { and observation are } \\
\text { not accurate. }\end{array}$ \\
\hline b. & $\begin{array}{l}\text { Format and } \\
\text { aesthetics } \\
\text { CO } 4\end{array}$ & $\begin{array}{l}\text { - Report is well } \\
\text { organized and } \\
\text { formatted. } \\
\text { - References are } \\
\text { according to IEEE } \\
\text { publication } \\
\text { standards. }\end{array}$ & $\begin{array}{l}\text { - Report is not well } \\
\text { organized and } \\
\text { formatted. } \\
\text { - References are not } \\
\text { according to } \\
\text { IEEE publication } \\
\text { standards. }\end{array}$ & & \\
\hline c. & $\begin{array}{l}\text { Figures and } \\
\text { Tables } \\
\text { CO4 }\end{array}$ & $\begin{array}{l}\text { - The figures and } \\
\text { tables are } \\
\text { complete, detailed } \\
\text { and formatted. }\end{array}$ & $\begin{array}{l}\text { - Figures are not } \\
\text { clear but tables } \\
\text { partially formatted } \\
\text { and detailed. }\end{array}$ & $\begin{array}{l}\text { - Figures and tables are } \\
\text { partially complete, } \\
\text { detailed and } \\
\text { formatted. }\end{array}$ & $\begin{array}{l}\text { - Improper } \\
\text { representation of } \\
\text { figures and tables. }\end{array}$ \\
\hline d. & $\begin{array}{l}\text { Ethics } \\
\text { CO4 }\end{array}$ & $\begin{array}{l}\text { - Report is } \\
\text { plagiarism checked } \\
\text { and acceptable. } \\
\text { - All the instructions } \\
\text { related to project } \\
\text { given throughout } \\
\text { the semester were } \\
\text { followed. }\end{array}$ & $\begin{array}{l}\text { - Report is } \\
\text { plagiarism } \\
\text { checked and } \\
\text { acceptable. } \\
\text { - Instructions given } \\
\text { throughout the } \\
\text { project course } \\
\text { were partially } \\
\text { followed. }\end{array}$ & & \\
\hline
\end{tabular}

Table 7. Rubrics for Phase 5 with CO mapping 


\section{Training 3: Workshop on Report Writing}

A final workshop is conducted at the end of Phase 4 to explain the importance of documentation and the procedure to write a good project dissertation report. Importance of plagiarism check and documentation ethics are also explained to the students.

\section{Program and Course Outcomes}

Computer Science and Engineering is a program of undergraduate studies in engineering. This program consists of courses that are spread across multiple semesters. The outcomes of the program and its involved courses are the metrics necessary in quantifying the learning of the student. A program outcome depends on course outcomes. Final year capstone project as a course, is a major contributor to the achievement of the program outcomes.

Program outcomes are defined as per the graduate attributes which adhere to Outcome based Education of Washington Accord. These are important criteria in the accreditation process of the institution. The program outcomes defined in the accord for Computer Science and Engineering are as listed below:

- PO1: Engineering Knowledge

- PO2: Problem Analysis

- PO3: Design/Development of solutions

- PO4: Conduct Investigations of Complex Problems

- PO5: Modern Tool Usage

- PO6: The Engineer and Society

- PO7: Environment and Sustainability

- PO8: Ethics

- PO9: Individual and Team Work

- PO10: Communication

- PO11: Project Management and Finance

- PO12: Life-long learning

The outcome of the course, final year project (FYP) is calculated by mapping the rubrics to the course outcomes. The course outcomes for final year project are defined as:

- CO1: Perform literature review; identify state of the art in technology and research in that field and use the literature study define the problem.

- CO2: Establish a methodology using advanced tools / techniques for solving the problem including project management and finances.

- CO3: Design, develop analytical models, perform numerical analysis and interpret the results

- CO4: Prepare quality document of project work for publications, patenting and final thesis.

The presentation given by each team in all the phases is evaluated by the committee and the guide. The final marks of each phase are calculated by taking 50\% of the total marks from the committee and 50\% from the guide marks. The evaluation structure and marks are as shown in Figure 3. 


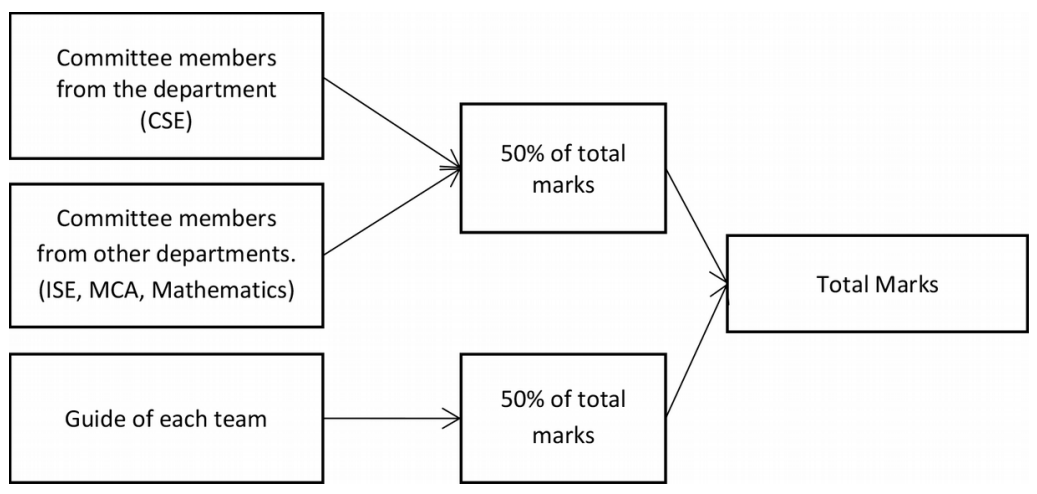

Figure 3. Evaluation of the Project by the Committee

\section{Attainment of Course and Program Outcomes}

\subsection{Attainment of Course Outcome Based on Rubrics}

Rubrics of all the phases conducted throughout the course are mapped to the course outcomes. The assigned marks by the committee and guide are tabulated and attainment of course outcome is calculated as follows:

$$
C O_{i} \text { for a student }=\frac{\text { Sum of Marks obtained across all the phases for } \mathrm{CO}_{i}}{\text { Maximum Marks for } \mathrm{CO}_{i} \text { across all the phases }}
$$

Where $\mathrm{CO}_{i}$ is the course outcome ranging from 1 to 4 . The course outcomes attained by all the students are averaged to calculate the cumulative course outcome of the course. Figure 4 shows the course outcome attained percentage for the final year projects for three years during the academic year 2014-15 to 2016-17.

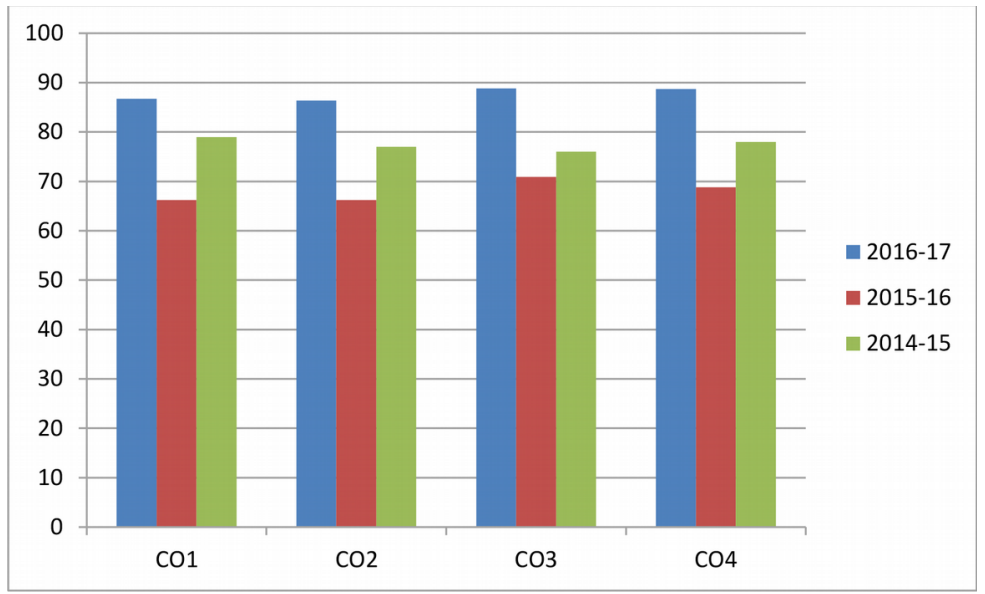

Figure 4. Course Outcome attained percentage for three years

\subsection{Attainment of Program Outcome Based on Course Outcome and Action Taken}

Program outcome is calculated from course outcome as follows.

Course Outcomes $\left(\mathrm{CO}_{i}\right)$ of the courses are mapped to Program Outcomes $(\mathrm{PO})$ by assigning a weightage based on relevance on a scale of low (1), medium (2) and high (3) as shown in Table 8 . The weightage is based on the extent to which the outcome is delivered in the form of teaching, training, incorporation in rubrics etc. 


\begin{tabular}{|c|c|c|c|c|c|c|c|c|c|c|c|c|}
\hline Cos & PO1 & PO2 & PO3 & PO4 & PO5 & PO6 & PO7 & PO8 & PO9 & PO10 & PO11 & PO12 \\
\hline CO1 & H & H & H & H & M & L & L & M & L & L & M & M \\
\hline CO2 & H & H & H & H & M & L & L & M & L & L & M & M \\
\hline CO3 & H & H & H & H & M & L & L & M & L & L & M & M \\
\hline CO4 & L & L & L & L & L & L & L & M & L & L & L & L \\
\hline
\end{tabular}

Table 8. The CO-PO weightage mapping for the year 2014-15 and 2015-16

where $\mathrm{H}$ is high, $\mathrm{M}$ is medium and $\mathrm{L}$ is low.

The $P O$ attainment of final year project course $=\frac{\left(\sum_{i=1}^{4} w_{i}{ }^{*} C O_{i}\right) / 4}{3 *\left(\sum_{i=1}^{4} C O_{i}\right) / 4} \times 100$

Where $w_{i}$ is weightage in the range $\left(1,2\right.$, and 3 ) allocated to $C O_{i}$. Denominator is course outcome multiplied by maximum value three or high.

Consider the course outcome for two academic years 2014-15 and 2015-16 as given in Table 9 or Figure 4.

\begin{tabular}{|c|c|c|c|c|}
\hline & CO1 & CO2 & CO3 & CO4 \\
\hline $2015-16$ & 66 & 66 & 71 & 69 \\
\hline $2014-15$ & 79 & 77 & 76 & 78 \\
\hline
\end{tabular}

Table 9. CO attainment for the years 2014-15 and 2015-16

Program outcome for the year 2014-15 and 2015-16 is as shown in Table 10.

For example, for the year 2014-15, PO1 is calculated as follows:

From Table 8, CO-PO weightage for PO1 is $(3,3,1)$ and CO attainment is $(79,77,76,78)$. Therefore from the above formula,

$$
\frac{(3 * 79+3 * 77+3 * 76+1 * 78) / 4}{3 *\left(\frac{79+77+76+78}{4}\right)} * 100=774 / 930=83.2
$$

\begin{tabular}{|c|r|r|r|r|r|r|r|r|r|r|r|r|}
\hline POs & PO1 & \multicolumn{1}{|c|}{ PO2 } & \multicolumn{1}{|c|}{ PO3 } & PO4 & \multicolumn{1}{|c|}{ PO5 } & PO6 & \multicolumn{1}{c|}{ PO7 } & \multicolumn{1}{c|}{ PO8 } & PO9 & PO10 & PO11 & PO12 \\
\hline $2015-16$ & 83 & 83 & 83 & 83 & 58.2 & 33.3 & 33.3 & 66.6 & 33.3 & 33.3 & 58.2 & 58.2 \\
\hline $2014-15$ & 83.2 & 83.2 & 83.2 & 83.2 & 58.2 & 33.3 & 33.3 & 66.6 & 33.3 & 33.3 & 58.2 & 58.2 \\
\hline
\end{tabular}

Table 10. Program Outcomes for the years 2014-15 and 2015-16

Since no changes were made in 2014-15 and 2015-16, the attainment remained constant. For the academic year 2016-17, changes were made as shown in Table 11. 


\begin{tabular}{|l|l|}
\hline $\begin{array}{l}\text { PO6 } \\
\text { Engineer and Society }\end{array}$ & $\begin{array}{l}\text { Projects related to society were given importance by adding it in the rubrics and } \\
\text { motivating students to take up topics related to society. Hence the relevance mapping is } \\
\text { also increased from Low (1) to Medium (2). }\end{array}$ \\
\hline $\begin{array}{l}\text { PO7 } \\
\text { Environment and } \\
\text { sustainability }\end{array}$ & $\begin{array}{l}\text { Projects related to environment were given importance by adding it in the rubrics and } \\
\text { motivating students to take up projects related to environment. Hence the relevance } \\
\text { mapping is also increased from Low (1) to Medium (2). }\end{array}$ \\
\hline $\begin{array}{l}\text { PO8 } \\
\text { Ethics }\end{array}$ & $\begin{array}{l}\text { Explaining students about the importance of plagiarism check and made it mandatory by } \\
\text { including it in the rubrics. Hence PO8 was increased from Medium (2) to High (3). }\end{array}$ \\
\hline $\begin{array}{l}\text { PO9 } \\
\text { Individual and Team } \\
\text { work }\end{array}$ & $\begin{array}{l}\text { Students were motivated to take up interdisciplinary projects and team structure was made } \\
\text { mandatory by including in the rubrics. Hence the relevance of PO9 was increased from } \\
\text { Low (1) to Medium (2). }\end{array}$ \\
\hline $\begin{array}{l}\text { PO10 } \\
\text { Project management } \\
\text { and Finance }\end{array}$ & $\begin{array}{l}\text { Project management was made mandatory by motivating students to plan finance and } \\
\text { project scheduling using Gantt chart and was added in rubrics for evaluation. Hence } \\
\text { relevance was raised from Low (1) to Medium (2). }\end{array}$ \\
\hline
\end{tabular}

Table 11. Action taken for the academic year 2016-17

The CO-PO weightage mapping for the year 2016-17 based on action taken is as given Table 12.

\begin{tabular}{|c|c|c|c|c|c|c|c|c|c|c|c|c|}
\hline Cos & PO1 & PO2 & PO3 & PO4 & PO5 & PO6 & PO7 & PO8 & PO9 & PO10 & PO11 & PO12 \\
\hline CO1 & $\mathrm{H}$ & $\mathrm{H}$ & $\mathrm{H}$ & $\mathrm{H}$ & $\mathrm{M}$ & $\mathrm{M}$ & $\mathrm{M}$ & $\mathrm{H}$ & $\mathrm{M}$ & $\mathrm{M}$ & $\mathrm{M}$ & $\mathrm{M}$ \\
\hline CO2 & $\mathrm{H}$ & $\mathrm{H}$ & $\mathrm{H}$ & $\mathrm{H}$ & $\mathrm{M}$ & $\mathrm{M}$ & $\mathrm{M}$ & $\mathrm{H}$ & $\mathrm{M}$ & $\mathrm{M}$ & $\mathrm{M}$ & $\mathrm{M}$ \\
\hline CO3 & $\mathrm{H}$ & $\mathrm{H}$ & $\mathrm{H}$ & $\mathrm{H}$ & $\mathrm{M}$ & $\mathrm{M}$ & $\mathrm{M}$ & $\mathrm{H}$ & $\mathrm{M}$ & $\mathrm{M}$ & $\mathrm{M}$ & $\mathrm{M}$ \\
\hline CO4 & $\mathrm{L}$ & $\mathrm{L}$ & $\mathrm{L}$ & $\mathrm{L}$ & $\mathrm{L}$ & $\mathrm{M}$ & $\mathrm{M}$ & $\mathrm{H}$ & $\mathrm{M}$ & $\mathrm{M}$ & $\mathrm{L}$ & $\mathrm{L}$ \\
\hline
\end{tabular}

Table 12. CO-PO weightage mapping for academic year 2016-17

Course outcome and Program outcome calculated from the Table 12 for the year 2016-17 is given in Table 13 and Table 14.

\begin{tabular}{|r|r|r|r|r|}
\hline & \multicolumn{1}{|c|}{ CO1 } & \multicolumn{1}{c|}{ CO2 } & \multicolumn{1}{c|}{ CO3 } & \multicolumn{1}{c|}{ CO4 } \\
\hline $2016-17$ & 87 & 86 & 89 & 89 \\
\hline
\end{tabular}

Table 13. Course outcome for the year 2016-17

\begin{tabular}{|c|r|r|r|r|r|r|r|r|r|r|r|r|}
\hline POs & \multicolumn{1}{|c|}{ PO1 } & \multicolumn{1}{|c|}{ PO2 } & \multicolumn{1}{|c|}{ PO3 } & \multicolumn{1}{|c|}{ PO4 } & \multicolumn{1}{|c|}{ PO5 } & \multicolumn{1}{|c|}{ PO6 } & PO7 & PO8 & PO9 & PO10 & PO11 & PO12 \\
\hline $2016-17$ & 83 & 83 & 83 & 83 & 58.2 & 66.6 & 66.6 & 100 & 66.6 & 66.6 & 58.2 & 58.2 \\
\hline
\end{tabular}

Table 14. Program Outcome for the year 2016-17

It can be observed that after action taken, the attainment of PO6 to PO10 in academic year 2016-17 has improved.

\subsection{Industry Feedback for Industry Projects}

Feedback is collected from the industry supervisors of the students who undertake live projects in industry. This feedback helps in calculation of attainment of program outcome. A feedback form is collected from companies which contains questions mapped to the program outcomes as shown below in Table 15. 


\begin{tabular}{|c|c|c|c|}
\hline S1. No. & Parameters & PO & $\begin{array}{l}\text { Please Tick the } \\
\text { appropriate grade }\end{array}$ \\
\hline \multirow{5}{*}{1} & \multirow{5}{*}{ Ability to apply mathematical concepts wherever required. } & \multirow{5}{*}{ PO1 } & Excellent (10) \\
\hline & & & Very Good (8) \\
\hline & & & Good (6) \\
\hline & & & Satisfactory (4) \\
\hline & & & Poor $(2)$ \\
\hline \multirow{5}{*}{2} & \multirow{5}{*}{$\begin{array}{l}\text { Understanding of computer science concepts, theories and } \\
\text { Programming languages. }\end{array}$} & \multirow{5}{*}{ PO2 } & Excellent (10) \\
\hline & & & Very Good (8) \\
\hline & & & Good (6) \\
\hline & & & Satisfactory (4) \\
\hline & & & Poor $(2)$ \\
\hline \multirow{5}{*}{3} & \multirow{5}{*}{$\begin{array}{l}\text { Ability to apply skills learnt, analyze the problem and find } \\
\text { efficient solutions and tools. }\end{array}$} & \multirow{5}{*}{ PO3, PO5 } & Excellent (10) \\
\hline & & & Very Good (8) \\
\hline & & & Good (6) \\
\hline & & & Satisfactory (4) \\
\hline & & & Poor (2) \\
\hline \multirow{5}{*}{4} & \multirow{5}{*}{ Problem Solving and critical thinking skills } & \multirow{5}{*}{ PO4 } & Excellent (10) \\
\hline & & & Very Good (8) \\
\hline & & & Good (6) \\
\hline & & & Satisfactory (4) \\
\hline & & & Poor $(2)$ \\
\hline \multirow{5}{*}{5} & \multirow{5}{*}{ Ability to work in a team } & \multirow{5}{*}{ PO9 } & Excellent (10) \\
\hline & & & Very Good (8) \\
\hline & & & Good (6) \\
\hline & & & Satisfactory (4) \\
\hline & & & Poor (2) \\
\hline \multirow{5}{*}{6} & \multirow{5}{*}{$\begin{array}{l}\text { Approach towards Environment and sustainability, society } \\
\text { and safety by the student. }\end{array}$} & \multirow{5}{*}{ PO7, PO6 } & Excellent (10) \\
\hline & & & Very Good (8) \\
\hline & & & Good (6) \\
\hline & & & Satisfactory (4) \\
\hline & & & Poor (2) \\
\hline \multirow{5}{*}{7} & \multirow{5}{*}{$\begin{array}{l}\text { Professional ethics and responsibilities demonstrated by the } \\
\text { student. }\end{array}$} & \multirow{5}{*}{ PO8 } & Excellent (10) \\
\hline & & & Very Good (8) \\
\hline & & & Good (6) \\
\hline & & & Satisfactory (4) \\
\hline & & & Poor $(2)$ \\
\hline \multirow{5}{*}{8} & & & Excellent (10) \\
\hline & & & Very Good (8) \\
\hline & Project management and finance skills & PO11 & Good (6) \\
\hline & & & Satisfactory (4) \\
\hline & & & Poor $(2)$ \\
\hline & & & Excellent (10) \\
\hline & & & Very Good (8) \\
\hline 9 & Communication skills & PO10 & Good (6) \\
\hline & & & Satisfactory (4) \\
\hline & & & Poor $(2)$ \\
\hline & & & Excellent (10) \\
\hline & & & Very Good (8) \\
\hline 10 & $\begin{array}{l}\text { ADillty to engage in independent and changing tecnnology } \\
\text { skill uporadation. }\end{array}$ & PO12 & Good (6) \\
\hline & & & Satisfactory (4) \\
\hline & & & Poor $(2)$ \\
\hline
\end{tabular}

Table 15. Feedback questions mapped to POs 
The feedback questions are mapped to program outcomes and are tabulated to calculate the attainment of PO. Industries are major stakeholders in the program. The outcome of program from feedback is calculated as:

$$
P O_{i} \text { attainment for a student }=\frac{\text { Sum of Rating obtained for } P O_{i} \text { in the form of feedback from industry }}{\text { Maximum rating for } P O_{i}}
$$

Where $P O_{i}$ are the Program outcomes ranging from 1 to 12.

The comparison of percentage of program outcome attained based on feedback from the industry is shown in Figure 5.

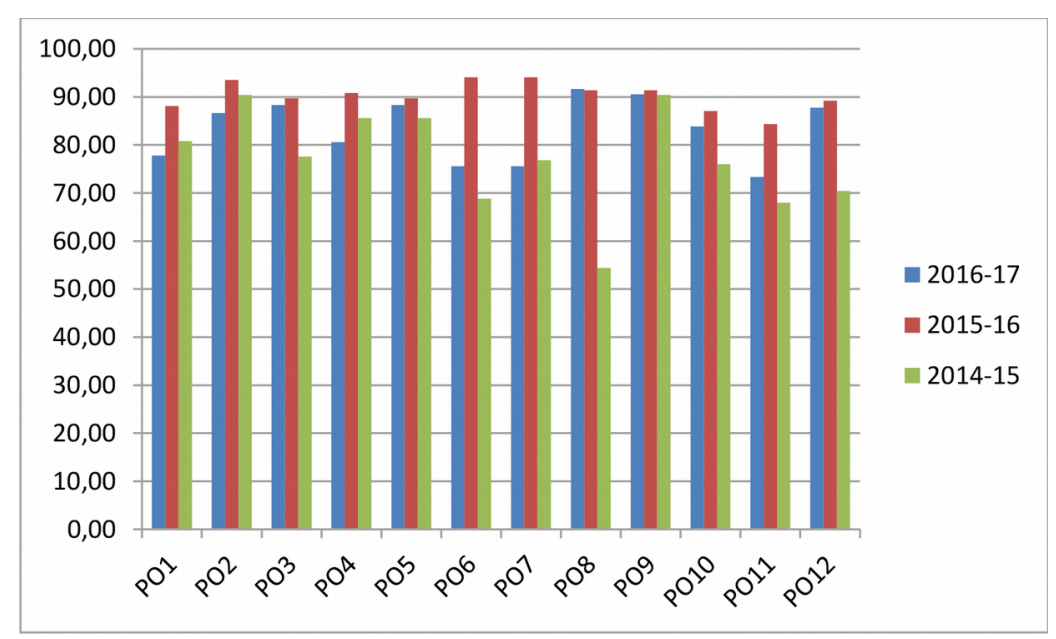

Figure 5. Program Outcome attained percentage based on Industry feedback

It can be observed that there is improvement in two years compared to attainment in 2014-15.

\subsection{Student Feedback About the Course}

An exit survey is conducted for the students after completion of the final year project course. The feedback questions are mapped to program outcomes and are tabulated to calculate the attainment of PO.

$$
P O_{i} \text { attainment for a student }=\frac{\text { Sum of Rating obtained for } \mathrm{PO}_{i} \text { in the form of feedback from }}{\text { student }}
$$

Where $P O_{i}$ are the Program outcomes ranging from 1 to 12 .

The average of program outcomes attained by all the students gives the overall attainment of PO for the program. The percentage of program outcome, attained based on feedback, for the year 2016-17 is as shown in the Figure 6.

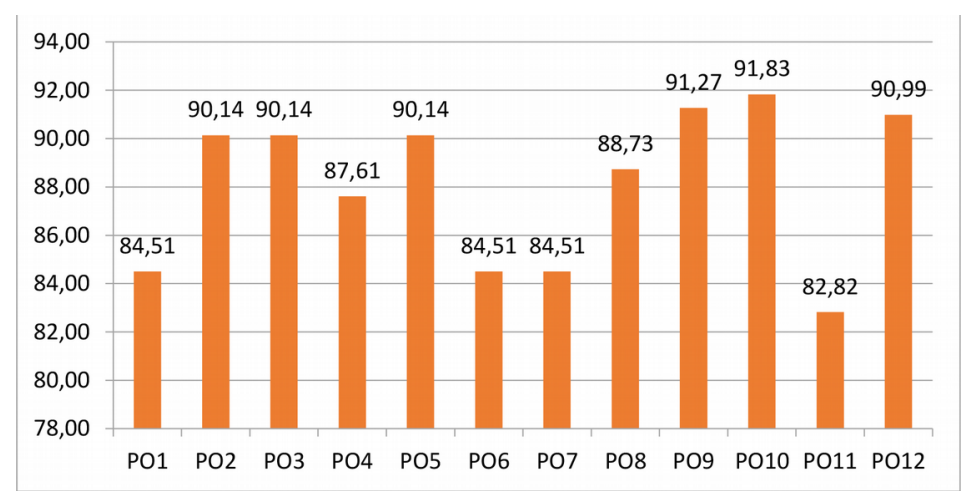

Figure 6. Program Outcome attained percentage based on Student feedback for the year 2016-17 


\section{Continuation of Projects}

Some complex projects are carried out for multiple academic years as in-house projects. These help in establishing an in-depth knowledge on the topic and create a prototype. An open source tool such as GitHub is used to maintain and update the source code across student batches. Faculty who guide such projects can publish or apply for project funding. Some examples of such projects are as shown in Table 16.

\begin{tabular}{|c|c|l|l|}
\hline S1. No. & Year & \multicolumn{1}{|c|}{ Topic } & \multicolumn{1}{|c|}{ Type of project } \\
\hline \multirow{2}{*}{1} & $2015-16$ & $\begin{array}{l}\text { Contextually Recommended Searching of Unstructured } \\
\text { Data using Machine Learning Techniques }\end{array}$ & Research work \\
\cline { 2 - 4 } & $2016-17$ & $\begin{array}{l}\text { Intellisearch: a search engine based on context based } \\
\text { search and retrieval of unstructured data. }\end{array}$ & Application \\
\hline \multirow{2}{*}{2.} & $2015-16$ & Object Counting In Video Sequences & Research Work \\
\cline { 2 - 4 } & $2016-17$ & Object tracking with occlusion handling in videos & Research work and Application \\
\hline 3 & $2015-16$ & Preprocessing and Segmentation of Historical Records & Research work \\
\hline 4 & $2016-17$ & Restoration and classification of historical records & Research Work \\
\hline
\end{tabular}

Table 16. Projects continued for two years

\section{Publications and Recognitions}

\subsection{Project Magazine}

After the final evaluation of the projects, a magazine called "Technonest" is published every year and preserved for future reference in the library. The magazine consists of project title, student names, guide names, industry details and the abstracts of the projects. The cover page of the magazine for the year 2016-17 is shown in Figure 7. Future students who are looking for related projects can go through the magazine to find them and the project reports of the related projects can be retrieved from the library.

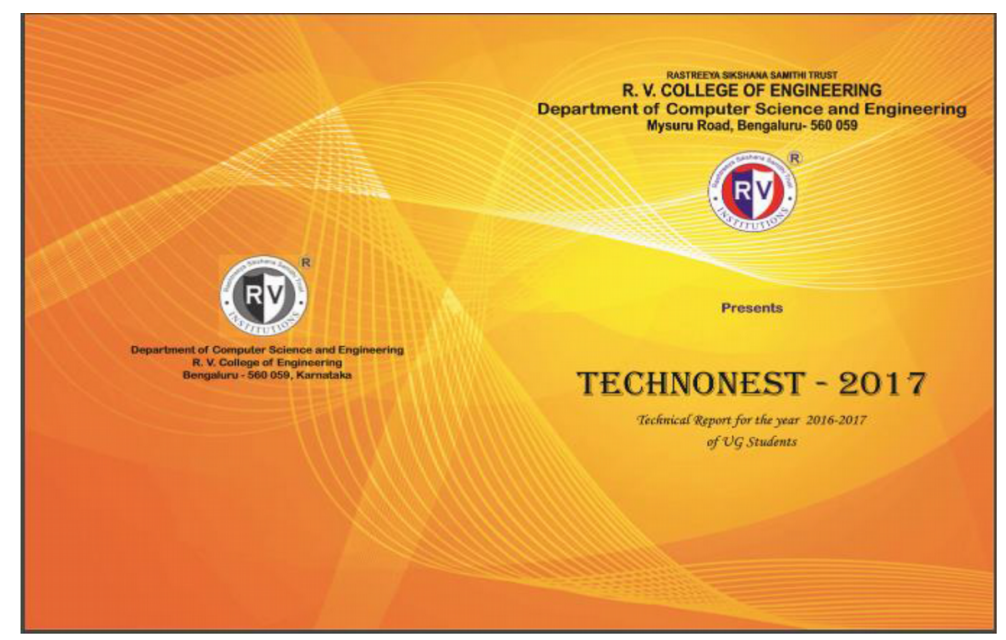

Figure 7. Collection of Abstracts "Technonest" magazine

\subsection{Best Project Prizes}

A system of appreciation for the best project is put in place to provide motivation. During phase 4, the committee recommends projects in that domain for best project evaluation. Evaluation of the best project is conducted for all these listed projects with industry experts as judges. Shortlisted projects are presented and demonstrated by the students. The judges then select three best projects among the shortlisted projects and these teams are awarded with prizes and certificates. 


\section{Observations}

The observations made after completion of final year project course from 2014-15 to 2016-17 are as follows:

1. Continuous evaluation of the course is achieved through phases and rubrics. Rubrics help in effective evaluation of the final year project.

2. Program outcome is evaluated based on course outcome and feedback from the industry and students. The program outcome has increased in 2016-17 and this is because of the observations made in the previous year and actions taken upon them.

3. Industry relationship with the academia is enhanced by taking feedback from the industry and improving on the places of lacuna. Improved program outcome is observed in the academic year 2016-17 based on feedback from industry. Furthermore, the number of industry projects has increased over the years.

4. Student feedback for the year 2016-17 shows that the students are satisfied with the conduction and evaluation of the course with an average of $88 \%$ program outcome attained.

5. Continuation of the project work by juniors helps the students and guides to go in-depth of the topic and to create a prototype, which helps the guide to apply for further funding from agencies.

\section{Conclusion}

Final year project is a very important course in Computer Science and Engineering undergraduate program. The course tests the student for his readiness to enter the corporate world. It also provides an exposure to, conducting research, effective documentation, project management and planning. The evaluation procedure discussed brings out the importance of rubrics for continuous evaluation and attainment of the course and program outcomes. The program can be improved through observations and actions taken based on attainment of outcomes. Therefore, this paper gives a holistic approach to the learning experience of student through capstone project.

\section{Declaration of Conflicting Interests}

The authors declared no potential conflicts of interest with respect to the research, authorship, and/or publication of this article.

\section{Funding}

The authors received no financial support for the research, authorship, and/or publication of this article.

\section{References}

Bell, S. (2010). Project-based learning for the 21st century: Skills for the future. The Clearing House, 83(2), 39-43. https://doi.org/10.1080/00098650903505415

Blumenfeld, P.C., Soloway, E., Marx, R.W., Krajcik, J.S., Guzdial, M., \& Palincsar, A. (1991). Motivating project-based learning: Sustaining the doing, supporting the learning. Educational Psychologist, 26(3-4), 369-398. https://doi.org/10.1080/00461520.1991.9653139

Darling-Hammond, L. (2006). Assessing teacher education: The usefulness of multiple measures for assessing program outcomes. Journal of Teacher Education, 57(2), 120-138.

https://doi.org/10.1177/0022487105283796

Dunlap, J.C. (2005). Problem-based learning and self-efficacy: How a capstone course prepares students for a profession. Educational Technology Research and Development, 53(1), 65-83.

https://doi.org/10.1007/BF02504858 
Durlak, J.A., \& DuPre, E.P. (2008). Implementation matters: A review of research on the influence of implementation on program outcomes and the factors affecting implementation. American Journal of Community Psychology, 41(3-4), 327-350. https://doi.org/10.1007/s10464-008-9165-0

Harris, D., \& Smith, B. (1983). Undergraduate project work. Assessment and Evaluation in Higher Education, 8(3), 246-261. https://doi.org/10.1080/0260293830080307

Healey, M., Lannin, L., Stibbe, A., \& Derounian, J. (2013). Developing and enhancing undergraduate final-year projects and dissertations. York: Higher Education Academy.

https://github.com/ (Accessed: May 2018).

Krajcik, J., \& Blumenfeld, P. (2006). Project-Based Learning. In Sawyer, R. (Ed.), The Cambridge Handbook of the Learning Sciences (Cambridge Handbooks in Psychology, 317-334). Cambridge: Cambridge University Press.

Ku, H., \& Goh, S. (2010). Final year engineering projects in Australia and Europe. European Journal of Engineering Education, 35(2), 161-173. https://doi.org/10.1080/03043790903497336

Mills, J.E., \& Treagust, D.F. (2003). Engineering education-Is problem-based or project-based learning the answer. Australasian Journal of Engineering Education, 3(2), 2-16.

StarUML, U.M.L. (2005). Modeling tool. Multilingual project. Version 5.0. 2.1570.

Stevens, D.D., \& Levi, A.J. (2013). Introduction to rubrics: An assessment tool to save grading time, convey effective feedback, and promote student learning. Stylus Publishing.

Tsvetkov, K. (2015). Project management by application of open source software ProjectLibre. 978-619.

Vijayalakshmi, M., Desai, P.D., \& Joshi, G.H. (2013). Outcome based education performance evaluation of capstone project using assessment rubrics and matrix. Innovation and Technology in Education (MITE), 2013 IEEE International Conference in MOOC. IEEE. https://doi.org/10.1109/MITE.2013.6756295

Published by OmniaScience (www.omniascience.com)

Journal of Technology and Science Education, 2018 (www.jotse.org)

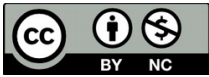

Article's contents are provided on an Attribution-Non Commercial 4.0 Creative commons International License. Readers are allowed to copy, distribute and communicate article's contents, provided the author's and JOTSE journal's names are included. It must not be used for commercial purposes. To see the complete licence contents, please visit https://creativecommons.org/licenses/by-nc/4.0/. 